https://doi.org/10.5719/aub-g/69.1/4

\title{
INTEGRATING CURVE NUMBER FLOOD MODEL AND GIS FOR FLOOD VULNERABILITY MAPPING IN NIGER STATE
}

\author{
ABIODUN OLUFEMI ADEBOLA ${ }^{1}$
}

\begin{abstract}
The research was conducted using Shuttle Radar Topographic Mission Satellite Image, Soil analysis, curve number flood model and Quantum GIS software to provide baseline information for the monitoring and management of flood disaster in Niger State, Nigeria. The SRTM image was used to analyse proximity of Niger State to rivers and create a Digital Terrain Model of Niger State based on elevation. Soil analysis was conducted to determine the types of soil indifferent locations in the state, the curve number model was used to calculate run-off values based on different land use types and soil types. These variables, rainfall intensity and duration, were imported into quantum GIS to generate a flood vulnerability map of Niger State. The research revealed two major causes of flood in Niger State namely primary causes such as soil type, rainfall intensity and duration; and secondary causes which include reservoir operations and building of structures along flood plains. Out of the $76,000 \mathrm{~km}^{2}$ covered by Niger State, $40 \%\left(30,000 \mathrm{~km}^{2}\right)$ was found to be highly vulnerable, $45 \%\left(34,000 \mathrm{~km}^{2}\right)$ was moderately vulnerable and the remaining $15 \%\left(11,400 \mathrm{~km}^{2}\right)$ had low vulnerability to flood. The study advocates evolvement and enforcement of an environmental policy to curtail unstainable agricultural activities on and discourage wanton destruction of environmental sensitive areas for unapproved developments.
\end{abstract}

Keywords: Flood Vulnerability Map, Digital Terrain Model, SRTM Image, Curve number Model, Baseline information and Quantum GIS.

\section{Introduction}

Human beings have always had to cope with disasters including floods, droughts, earthquakes, volcanic eruptions, too much or too little

1 Federal University of Technology, Akure, Department of Remote Sensing and GIS; E-mail: aoadebola@futa.edu.ng 
rainfall, and the likes. A natural hazard in itself does not cause a disaster; a disaster results when a natural hazard impacts on a vulnerable, exposed and or ill-prepared community. River and coastal flooding are the most frequently occurring natural disasters and are increasing in occurrence more rapidly than any other natural disaster. World Bank report has shown that flooding is not only the most frequent natural hazard - it is also the disaster with the greatest economic and humanitarian impact in terms of number of people affected and in terms of economic asset exposure; that is buildings, transport infrastructure, utility infrastructure and other assets (Shi and Wang, 2010).

People in developing countries are particularly vulnerable to flood as they often live in high-risk areas, have lower coping capacities, and have limited or no risk cover in the form of insurance or other safety nets. A cornerstone of Disaster Risk Reduction is the Hyogo Declaration, made at the World Conference on Disaster Reduction in Kobe, Hyogo (Japan). This sets out the Hyogo Framework for Action (HFA) (2005-2015). Signed by 168 countries, its overarching goal is to build the resilience of nations and communities to disasters by achieving substantive reduction of disaster losses by 2015. Since the adoption of the HFA, many efforts have been made at the global, regional, national and local levels to address Disaster Risk Reduction systematically (UNBCPR, 2005).

The problem of flood is a global problem that has no boundaries. Though, the extent of destruction is cushioned from country to country, depending on her level of technological advancement, developing nations are ill-prepared and thus most affected. Floods are not peculiar to Nigeria, but the 2012 floods were considered the worst in the nation's history. The heavy rains precipitated overflow of river banks due to blocked drains which led to flood disasters across the country in 2012. This incidence had further exposed Nigeria and Nigerians to flood vulnerability and also showed the level of preparedness in states and the nation as a whole.

Preparation for flood emergencies in Niger State is poor, the overall risk to society, the economy and the environment is high because every year lives are lost and properties worth millions of Naira are destroyed. This study therefore attempts to develop a flood 
vulnerability map for the whole of Niger State with a view to generating baseline information for effective control and monitoring of flood disaster in the study Area.

\section{Materials and Methods}

\section{Research locale}

Niger State is located between latitudes $8^{\circ} 20^{\prime} \mathrm{N}$ and $11^{\circ} 30^{\prime} \mathrm{N}$ and longitude $3^{\circ} 30^{\prime} \mathrm{E}$ and $7^{\circ} 20^{\prime} \mathrm{E}$ as shown in Fig 1 . The state is bordered to the north by Zamfara State, to the north-west by Kebbi State, to the south by Kogi State, to the south-west by Kwara State; while Kaduna State and the Federal Capital Territory border the state to the north-east and south-east, respectively (Niger State Bureau of Statistics, 2011b)

Furthermore, the State shares a common international boundary with the Republic of Benin at Babanna in Borgu Local Government Area of the state. The state covers a total land area of about 76,000 sqkm, about 8.23 percent of Nigeria's total land area (Niger State Bureau of Statistics, 2011c)

River Niger flows through Niger State and has other tributaries in the state. Niger State is a state in the western part of Nigeria and the largest state in the country. The state capital is Minna, and other major cities are Bida, Kontagora, and Suleja. The state is named after River Niger. Three of Nigeria's major hydroelectric power stations, the Kainji Dam, Jebba dam and the Shiroro Dam, are located in Niger State; also situated there is Kainji Lake National Park, the largest National Park in Nigeria, which contains Kainji Lake, the Borgu Game Reserve and the Zugurma Game Reserve (Niger State Bureau of Statistics, 2011a)

Niger State is covered by two major rock formations the sedimentary and basement complex rocks. The sedimentary rocks to the south are characterized by sandstones and alluvial deposits, particularly along the Niger valley and in most parts of Borgu, Bida, Agaie, Lapai, Mokwa, Lavun, Gbako and Wushishi Local Government Areas.

This area also contains the extensive flood plains of the River Niger and this has made the state to be one of the largest and most fertile 
agricultural lands in the country. It also provides the best area for rice growing in Nigeria. Perhaps this may account for the location of the National Cereals Research Institute at Badeggi in the State.

To the north is the basement complex, characterised by granitic outcrops or inselbergs which can be found in the vast topography of rolling landscape. Such inselbergs dominate the landscape in Rafi, Shiroro, Minna, Mariga and Gurara Local Government Areas (Niger State Bureau of Statistics 2011d).

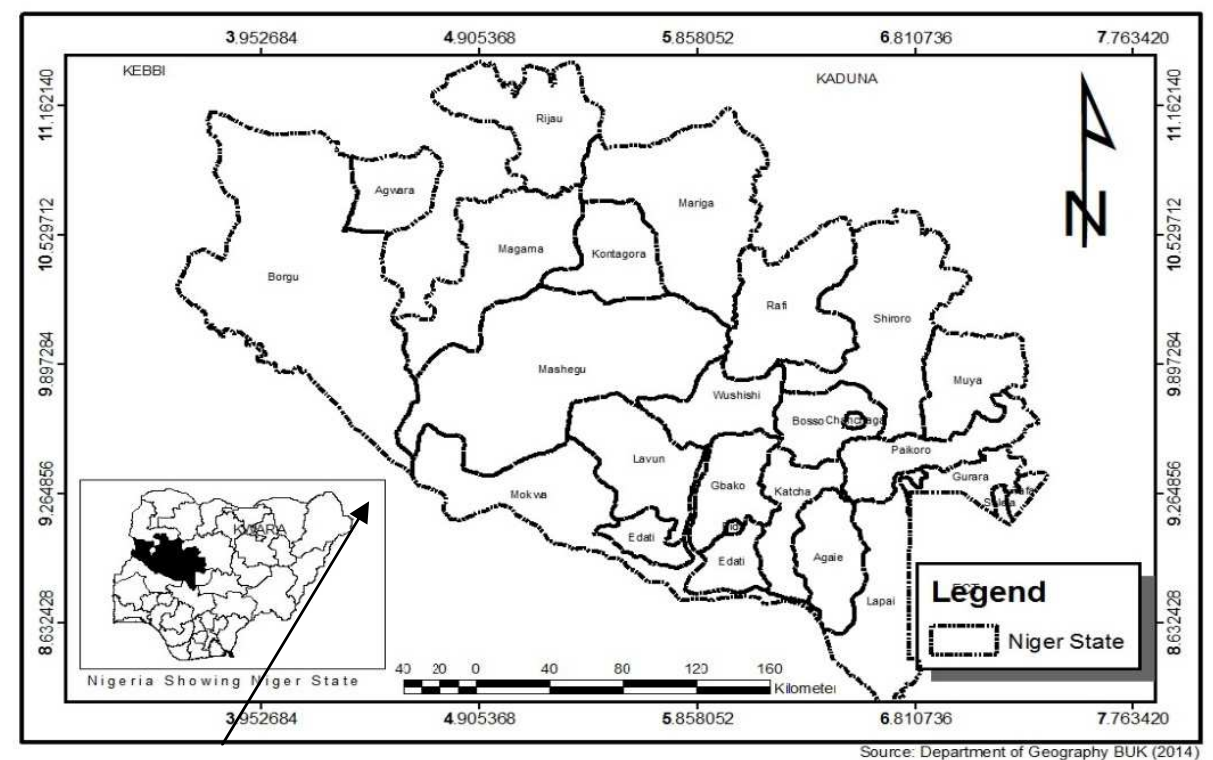

Fig. 1. Niger State

Source: Adapted from Google map

Niger State has a tropical wet and dry climate; the two seasons are controlled by the interplay of the North-East trades, Monsoon moist winds and the Inter-tropical Convergence Zone (ITCZ). Rainfall begins in April and terminates in October and total range is between 1000-1400 mm. the duration of sunshine per day combined with solar-radiation intensity are two important parameters that determine the drying power of the ambient air under low relative humidity values. Other elements of 
climate that affects flood in Niger State are discussed in details in this section (Adefolalu \& Oguntoyinbo, 2005a).

The State experiences two distinct seasons the dry and wet seasons. The duration of the rainy season ranges from 150-210 days from the north to the south, this is diagrammatically represented in Fig 2 . The annual rainfall varies from about $1,600 \mathrm{~mm}$ in the south to $1,200 \mathrm{~mm}$ in the north, mean annual rainfall and mean length of rainy season is shown in Fig 2 and 3 (Adefolalu, 1986).

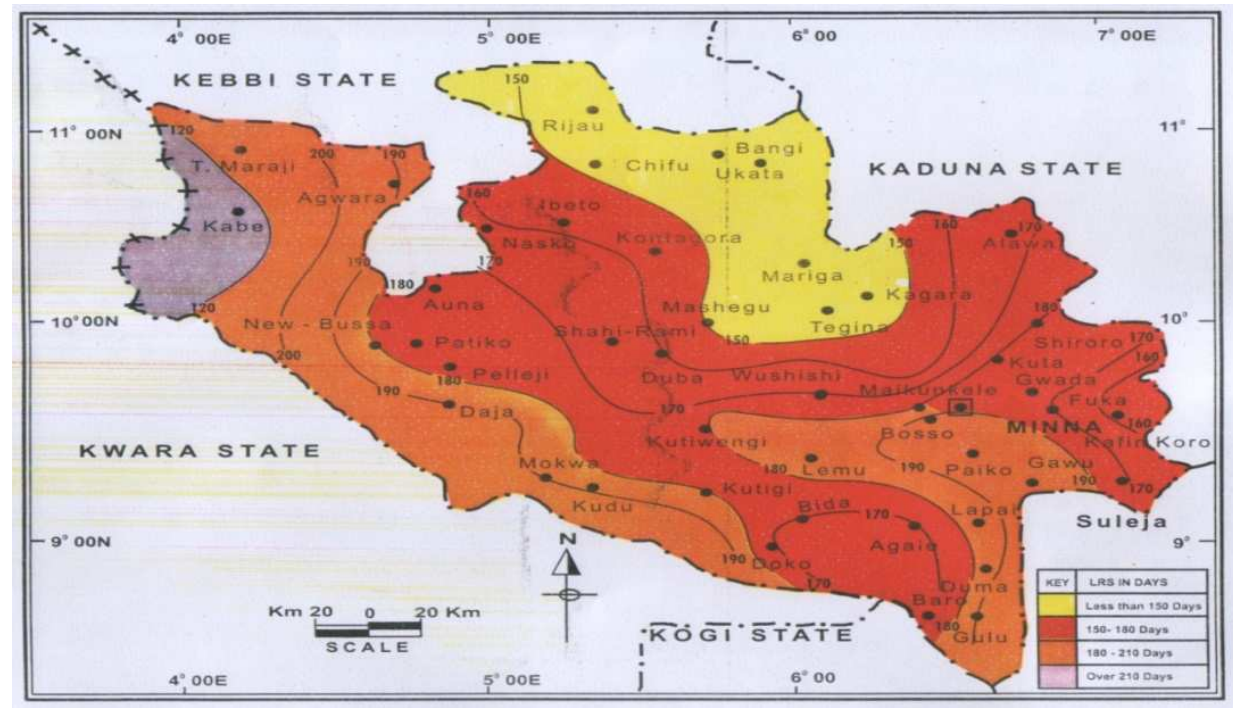

Fig. 2. Mean Length of Rainy Season in Days Source: CCCFWR, FUT, Minna (2009)

Onset of rains vary from place to place in Niger State, in some places, the rains start after $20^{\text {th }}$ May, while others start before $20^{\text {th }}$ April, as shown in Fig 4. Mean onset dates and Mean cessation Dates for rainfall is shown in Fig 4 and Fig 5. 


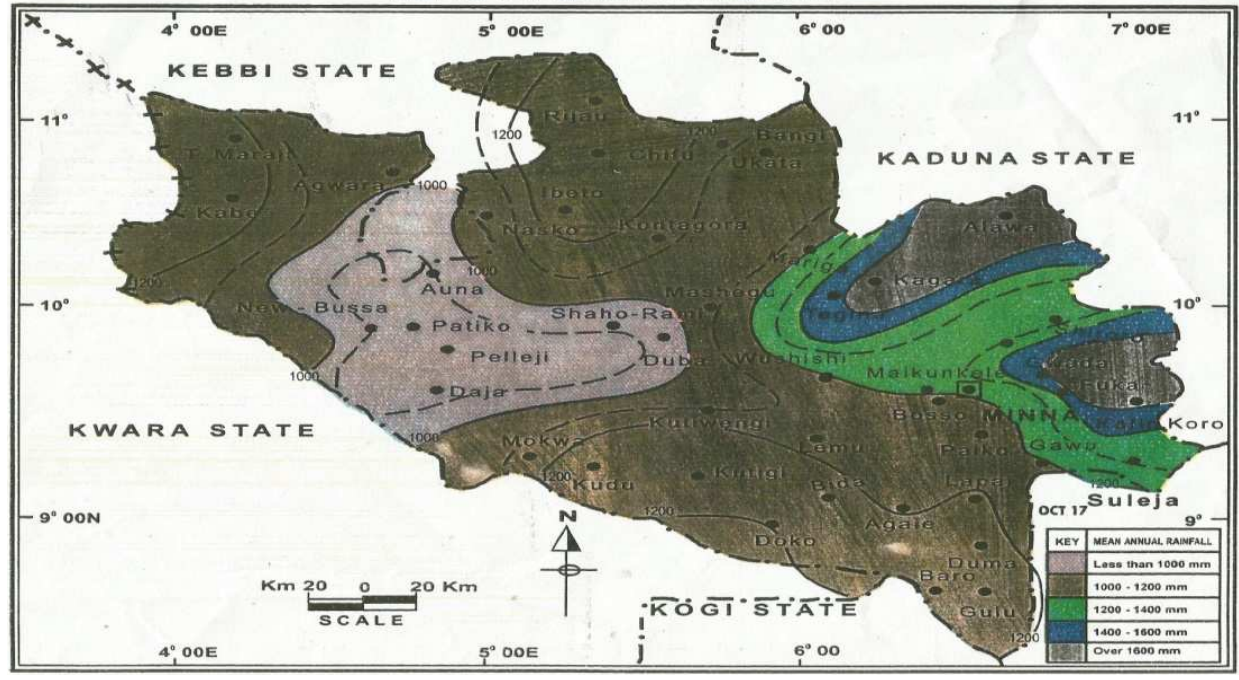

Fig. 3. Mean Annual Rainfall. Source: CCCFWR, FUT, Minna (2009)

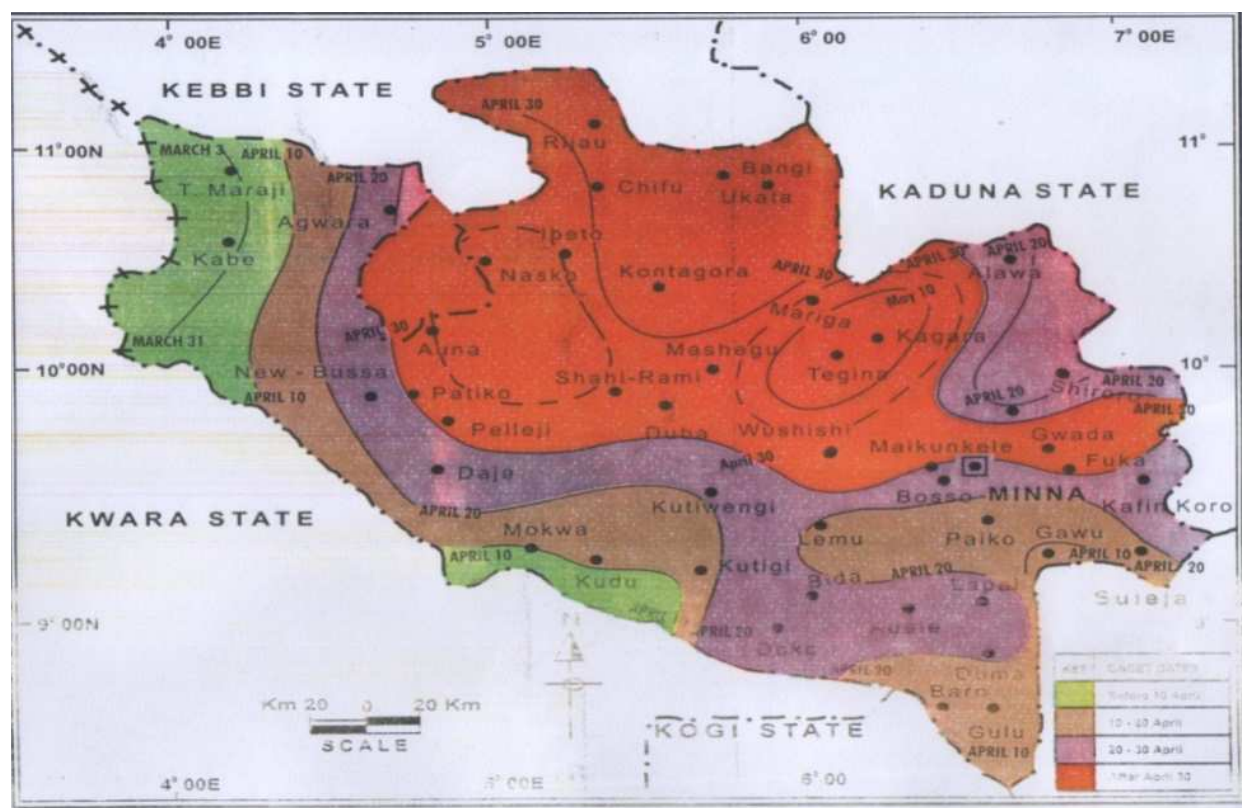

Fig. 4. Mean Onset Dates for Rainfall Source: CCCFWR, FUT, Minna (2009) 


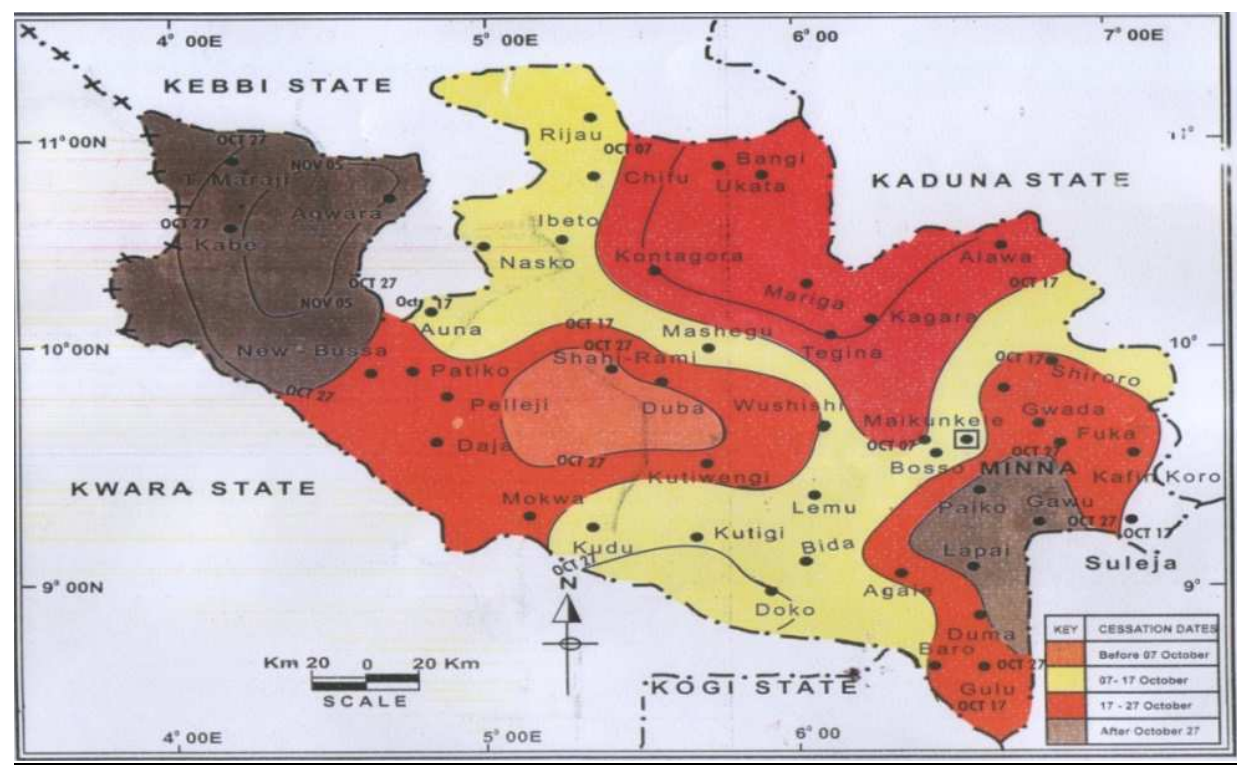

Fig. 5. Mean cessation Dates for Rainfall Source: CCCFWR, FUT, Minna (2009)

Mean maximum temperature remains high throughout the year, hovering about $32^{\circ} \mathrm{C}$, particularly in March and June. However, the lowest minimum temperatures occur usually between December and January when most parts of the state come under the influence of the tropical continental air mass which blows from the north. Dry season in Niger State commences in October. (Adefolalu \& Oguntoyinbo 2005b)

Three major soil types thatcan be found in the State include the ferruginous tropical soils, hydromorphic soils and ferrosols. The most predominant soil type is the ferruginous tropical soils which are basically derived from the Basement Complex rocks, as well as from old sedimentary rocks. Such ferruginous tropical soils are ideal for the cultivation of guinea corn, maize, millet and groundnut (Adams, 1985).

Hydromorphic or waterlogged soils are largely found in the extensive flood plain of the Niger River. The soils are poorly drained and are generally greyish or sometimes whitish in colour due to the high content of silt. Ferosols which developed on sandstone formations can be found within the Niger trough. Their characteristic red color enriched with a clay sub soil is noticeable in the landscape. Termite hills dot the 
landscape, particularly between Mokwa, Bida and Kontagora. These can be seen along the major highways in the state. The Southern Guinea Savannah vegetation covers the entire landscape of the state. It is characterized by woodlands and tall grasses interspersed with tall dense species. However, within the Niger trough and flood plain region occurs tall trees and a few oil palm trees. In some areas, traces of rain forest species can be seen (Adams, 2000).

Niger State is one of the states battling with one form of ecological problem or the other since its creation in 1976. The situation degenerated with the construction of dams at Jebba, Kainji and Shiroro, resulting in flood problems occurring virtually every year. This is also apart from some areas like Rijau, Nasko and Magama that are prone to desertification. The State Government had at different times warned on the rate of desertification, noting that farming activities might soon be grounded. To combat this, tree planting projects had been aggressively embarked on. The state also experiences flooding as a result of the construction of the three hydro-electric dams in Niger State by the Federal Government which has been causing flooding of the lower part of the state and which incidentally accounts for about 60 per cent of the entire land area spread across two of the state's geopolitical zones (Adams, 2000b).

On annual basis, several hectares of farmland and property are usually lost in addition to loss of lives to flood either from water releases from the dams or as a result of heavy rainfall.In year 2010, over 250 communities were sacked from their communities. The area mostly affected is Muregi. Six people lost their lives, while several hundreds were rendered homeless as a result of the flood, the third to affect Muregi community in Bida Local Government Area of Niger State in a space of two years. According to Timothy (2012), it was realized that villagers had been fleeing the area in their hundreds while all economic activities had been dormant. Other places affected are Wuya Kede, Muye and Akere (NSEMA 2012b). 
INTEGRATING CURVE NUMBER FLOOD MODEL AND GIS

FOR FLOOD VULNERABILITY MAPPING IN NIGER STATE

\section{Nature of Data}

\section{Shuttle Radar Topography Mission Satellite Image}

The Shuttle Radar Topography Mission (SRTM) is an international research effort that obtains digital elevation models on a near-global scale from $56^{\circ} \mathrm{S}$ to $60^{\circ} \mathrm{N}$, to generate the most complete high-resolution digital topographic database of digital elevation models around the globe. The Digital Terrain Model (DTM) of Niger State came in $90 \mathrm{~m}$ resolution, so it was resampled to $50 \mathrm{~m}$ to get a better result for the vulnerability zones. The re-sampling was done with Global Mapper. The resampled image downloaded from the site is shown in Fig 6.

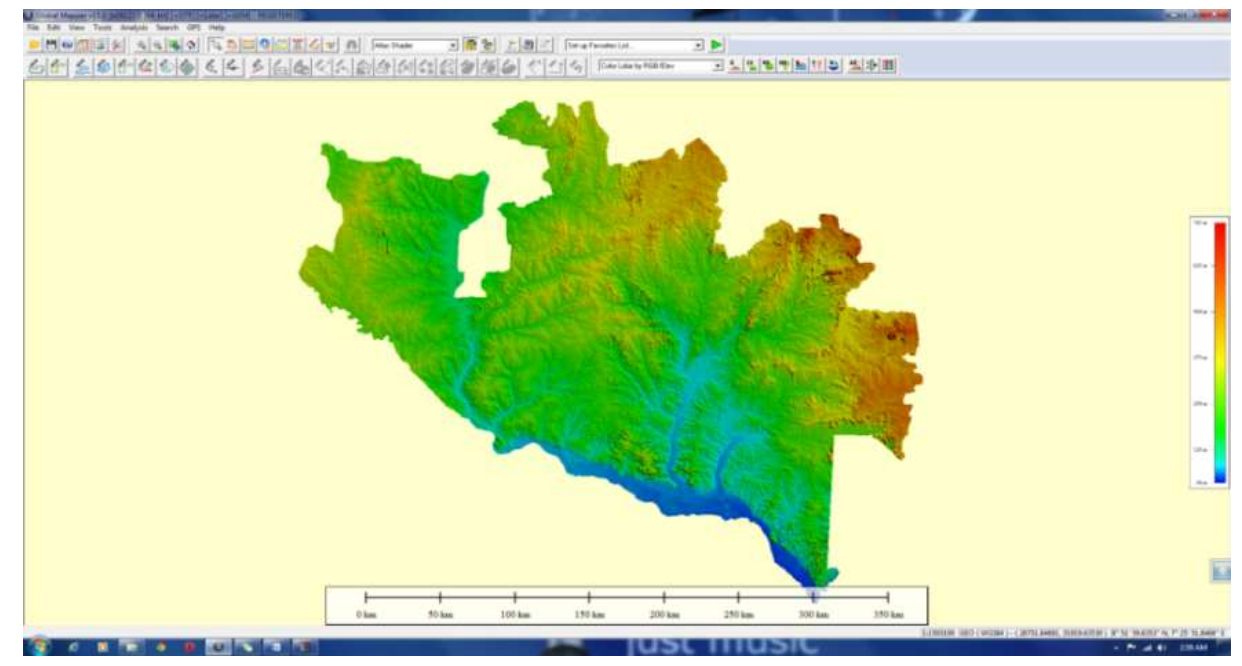

Fig. 6. SRTM Image of Niger State

From the DEM data loaded within the Global Mapper environment a contour map was generated, the contour was generated in polygon format so as to give an impression of the Area of Interest (AOI). The Digital Elevation Model was used to classify the state into vulnerable zones using height above lowest point in Niger State and proximity to water bodies in the state as basis for classification. 


\section{Rainfall Data}

Rainfall intensity, rainfall duration and mean annual rainfall were collected from different weather stations namely, Minna, Suleja, Bida, Rijau, Badeggi, Kontagora, Lapai, Shiroro, Mokwa, and Jebba. The data was used to determine which of the rainfall variables constituted the primary cause of flood in Niger state. Rainfall intensity, rainfall duration and mean annual rainfall map generated by the Center for Climate Change and Fresh water Resources Federal University of Technology, Minna, were also used as standard classification criteria for areas with different rainfall intensity, mean annual rainfall and duration. The essence of this was to group the causes of flood in Niger State into two major groups; the primary and the secondary causes of flood.

\section{Reconnaissance survey and Field observation}

An initial survey was carried out to get first-hand information on the study area concerning up-to-date flood situations in the state, and to interact with the people especially those affected by flood in 2012. A survey was carried out to ascertain which communities were affected by flood and to what extent they were affected and also to determine the agricultural land that was destroyed in the 2012 floods. Soil samples were taken during the field observation exercise and GPS readings were taken and recorded.

\section{Run-off properties of soil using curve number}

The curve number model developed by United States Natural Resources Conservation Service is an empirical parameter used in hydrological study for predicting direct run-off or infiltration from rainfall excess. Based on the rainfall intensity map of Niger State, the state was divided into 5 zones, soil samples was taken purposively from each area and test carried out on each to get infiltration rate using curve number. It is given by 


$$
Q=-\frac{(P-I a) 2}{P-I a+S}
$$

$$
\begin{aligned}
& \text { Where } \mathbf{Q}=\text { Runoff } \\
& \mathbf{P}=\text { Rainfall } \\
& \mathbf{S}=\text { the potential maximum soil retention after runoff begins } \\
& \text { Ia = the initial abstraction or the amount of water before } \\
& \text { runoff, such as infiltration or rainfall interception by vegetation. } \\
& \text { (USDA-SCS, 1972; Williams, 1995) }
\end{aligned}
$$

It is generally assumed that $\mathbf{I a}=0.2 \mathrm{~S}$

The runoff curve number $\mathrm{CN}$ is then related as $\mathrm{S}=\_\underline{\mathbf{1 0 0 0}}-\mathbf{1 0}$

$\mathrm{CN}$

CN has a range from 30 to 100; lower numbers indicate low runoff potential while larger numbers are for increasing runoff potential. The lower the curve number, the more permeable the soil is.

\section{Computing Runoff volume}

In computing the runoff volume, the following steps were followed:

a) Compute the Surface Storage: $S=(1000 / C N)-10$

b) Compute the Initial Abstraction: $\mathrm{Ia}=0.2 \times \mathrm{S}$

c) Compute the runoff in Inches: $Q=(P-I a) 2 /(P-I a+S)$

d) Convert from inches to millimetres

Rainfall intensity, soil type, land use type, rainfall duration, approximate distance from rivers and elevation above sea level are all imputed into the quantum GIS software and a vulnerability map was generated for Niger State based on the studied variables.

\section{Laboratory Techniques}

The laboratory techniques used in this study include standard procedures for determining particle size distribution of gravel, sand, silt 
and clay. This is to measure infiltration rate of each soil type in the state and relate it to rainfall intensity and duration to see at what point infiltration becomes zero. The procedure used in generating the map

\section{Generation of Flood Vulnerability Map}

The absolute location of the study area (Latitude and Longitude) was determined using a Global Positioning System. The latitude, longitude and height represented by $\mathrm{X}, \mathrm{Y}$ and $\mathrm{Z}$ coordinates from the GPS and SRTM image were used to generate digital elevation model for the study area. The vulnerability of the study area based on height was determined from the digital elevation model. Coordinates from GPS Garmin 75 and satellite image was imported into Global Energy mapper where the elevation values for different points in the state were extracted and a digital elevation model was generated from Quantun GIS software. A vulnerability map of Niger State was developed based on elevation above sea level, land use type and proximity to natural and man-made water bodies. The high, moderate and low vulnerability areas were digitized in the Quantum GIS environment.

\section{Results and Discussion}

\section{Rainfall intensity and soil type}

According to the Centre for Climate Change and Fresh Water Resources Federal University of Technology, Minna, rainfall intensity in Niger State ranged from $0 \mathrm{~mm} / \mathrm{hr}$ to $70 \mathrm{~mm} / \mathrm{hr}$. Surface runoff, consequent on high intensity of above $50 \mathrm{~mm} / \mathrm{hr}$ which was aggravated by soil type, slope and settlement pattern,was one of the major causes of flood in Niger State. Niger State had five mean rainfall intensity levels as shown in (Fig 7). These places with different levels of intensity were associated with mean rainfall intensity of less than $36 \mathrm{~mm} / \mathrm{hr}, 36-40 \mathrm{~mm} / \mathrm{hr}, 40-50 \mathrm{~mm} / \mathrm{hr}, 50-60 \mathrm{~mm} / \mathrm{hr}$, $60-70 \mathrm{~mm} / \mathrm{hr}$. Aparently, rainfall intensity, infiltration rate of soil and topography (mainly slope) all contributed to runoff in Niger State. 
INTEGRATING CURVE NUMBER FLOOD MODEL AND GIS FOR FLOOD VULNERABILITY MAPPING IN NIGER STATE

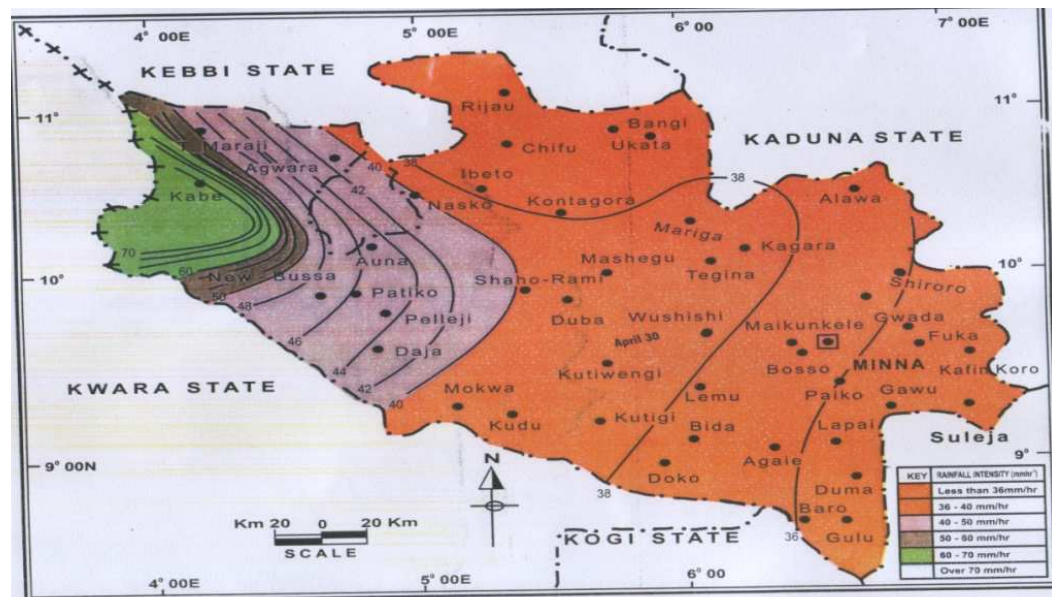

Fig. 7. Rainfall intensity for Niger State Source: Adapted from CCCFWR, 2009

The result of the soil tests undertaken to determine the texture of the soils in the study area was given in Table 1. Soil texture was modelled after United States Department of Agriculture soil textural classification.

Soil Texture in the Study Area

\begin{tabular}{|c|c|c|c|c|c|}
\hline Rainfall Intensity Area (mm/hr) & $\mathbf{0 - 3 5}$ & $\mathbf{3 6 - 4 0}$ & $\mathbf{4 0 - 5 0}$ & $\mathbf{5 0 - 6 0}$ & $\mathbf{6 0 - 7 0}$ \\
\hline Gravel (Laterites \%) & 14 & 0 & 11 & 0 & 0 \\
\hline Sand (\%) & 52 & 95 & 10 & 98 & 72 \\
\hline Silt (\%) & 13 & 5 & 18 & 2 & 13 \\
\hline Clay (\%) & 21 & 0 & 61 & 0 & 15 \\
\hline Soil textural class (USDA textural triangle) & GSC & S & GC & S & LS \\
\hline GSC - Gravel, sand and clay \\
\hline S - Sand \\
\hline GC - Gravel and sand \\
\hline
\end{tabular}

Source: Field work, 2013

Table 1 showed that the soils in the state contained more of sand, than clay and gravel. This means that infiltration and percolation is low. There is very little quantity of rainfall that percolates into the soil and a large amount flows as runoff. Considering the intensity and duration of 
rainfall in the state and relating it to infiltration rate, it is obvious that places with high rainfall intensity tend to have higher runoff. However, there are other factors that aggravate flood problems in Niger State, these factors show that making a definite assumption that places with higher rainfall intensity have higher runoff and thus experience flood more than places with low rainfall intensity may not be correct for all times and conditions. Some secondary factors aggravate flood beyond the primary causes. These factors are land use type, construction of residential buildings on flood plains and reservoir operations. These secondary factors are products of the primary factors and thus cannot be studied in isolation, hence the need to establish the secondary causes of flood in Niger State.

\section{Land use type}

The major land use types in Niger State are residential, commercial, agricultural and open land. The residential area is further divided into two based on population density. There is no place in Niger State with high population density, what is obtainable is medium and low population density. Soil type that was collected from each land use type in each rainfall intensity stratum was analysed using the curve number model, the results were presented in Fig 8.

The result from Fig 8 showed that land use type was one of the secondary factors that triggered runoff. The study identified rainfall and soil type as the primary causes of flood in Niger State. Relating rainfall intensity and soil type with land use types, helped to determine the rate of infiltration and runoff for each land use type. 


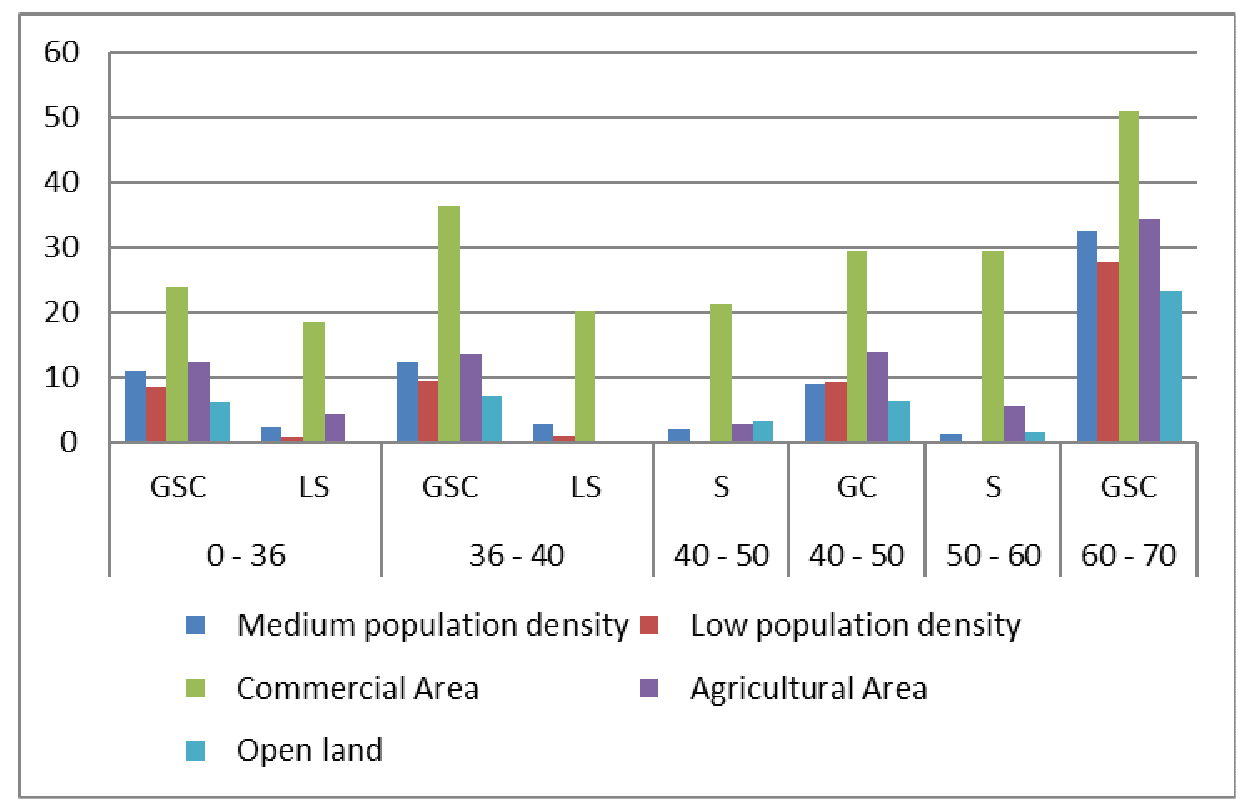

Fig. 8. Runoff values for different land use types

Figure 8 shows the difference in runoff for each land use type; firstly, there is difference in runoff for places with the same soil type and same rainfall intensity but different land use types. Areas with rainfall intensity of between $0-36 \mathrm{~mm} / \mathrm{hr}$ with soil type characterized by a mixture of gravel, sand and clay and infiltration of between 0-1.27 $\mathrm{mm} / \mathrm{hr}$ are places with actual runoff of $11.13 \mathrm{~mm} / \mathrm{hr}$, while places with low population density even though they are both residential areas, have actual runoff of $8.44 \mathrm{~mm} / \mathrm{hr}$. Commercial area have the highest amount of runoff of $23.78 \mathrm{~mm} / \mathrm{hr}$, while open land has the lowest amount of runoff of $6.25 \mathrm{~mm} / \mathrm{hr}$. The low amount of runoff for open land is because the flow pattern and drainages on the soil have not been tampered with. Agricultural area is next in high amount of runoff; this is caused by regular cultivation which has loosened the top soil thereby making the flow of water on the surface free especially along slopes. In contrast, places with soil type characterized by gravel, sand and clay to areas with loam and sand within the zone of $0-36 \mathrm{~mm} / \mathrm{hr}$ of rainfall intensity have different runoff rates. Though soil type in the commercial area has the highest runoff rates, the runoff is less than that of the 
Medium Population Density areas. This shows that land use type affects runoff in Niger State.

In other places in the state with different rainfall intensity and soil type, commercial areas have the highest runoff; places with medium population density area are next, while open area have the least runoff incidence. Agricultural land and low population density areas have runoff greater than open land. This is in tandem with the findings of Swaroop (2005), Munich Reinsurance (2002), NIOSH (2003) and Ologunorisa (2006), which states that land use type is a major factor that contributes significantly to flood problems in Nigeria and around the world.

\section{Reservoir Operations}

There are three major dams in Niger State, Nigeria. The Kainji Dam built in 1968, Jebba Dam built in 1985 and Shiroro Dam built in 1990. A fourth dam is being built at Zungeru, also in Niger State. These are all hydroelectric dams that generate a potential combined power output of 1,900 megawatts.

Dams in Niger State and their Characteristics

\begin{tabular}{|c|c|c|c|}
\hline Dam & Capacity $\left(\right.$ Million $\mathbf{~ m}^{\mathbf{3}}$ ) & Surface Area & Primary Usage \\
\hline Jebba & 3600 & 35,000 & HEP \\
\hline Kainji & 15000 & 130,000 & HEP \\
\hline Shiroro & 2700 & 31,200 & HEP \\
\hline
\end{tabular}

Source: David \& Adebayo, 2012 


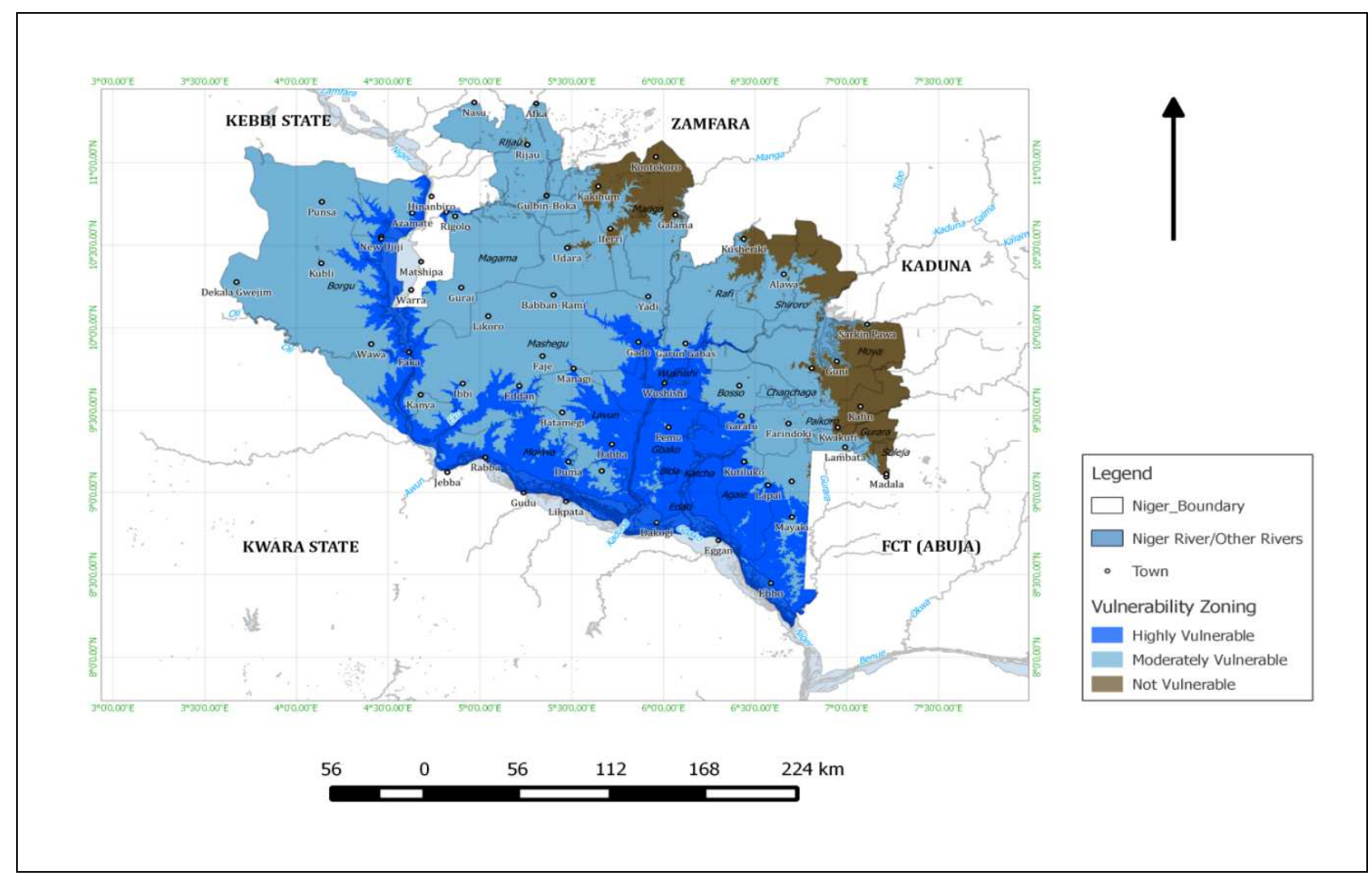

Fig. 9. Flood Vulnerability Map of Niger State 
From the vulnerability map as shown in Fig 9, the highly vulnerable, moderately and low vulnerable areas to flood have been clearly established.The vulnerability map of the state also shows that 19 out of the 25 Local Government Area in the state are vulnerable to flood, while only six are not vulnerable to flood. Even then, these six Local Government Areas (LGAs) are not completely free of flood events, a small part of these LGAs are vulnerable to flood. The LGAs are: Mariga, Munya, Shiroro, Rafi, Gurara and Suleja. Some of these areas are located in the highland regions in the state, and have never been affected by flood in the history of Niger State. Indeed the worst floods to have hit the state in recent times the 2012 and 2013 floods, did not affect any of these places. The study identified two major causes of flood in Niger State, namely; primary which includes; soil type, rainfall intensity, rainfall duration and secondary sources which include reservoir operations and building of structures along flood plains. It further established that highly vulnerable places are places with close proximity to the Rivers in the state, especially rivers Niger and Kaduna.

\section{Conclusion}

The study revealed two major causes of floods in the State namely primary and secondary causes. The primary causes identified are soil type, rainfall intensity and rainfall duration while the secondary causes include reservoir operations and building of structures along the flood plains. It further established that highlyvulnerable places were places with close proximity to the Rivers in the state, especially rivers Niger and Kaduna that coincided with the places that have been affected by flood in the past fall within these highly vulnerable zones. The vulnerability map of the state also shows that 19 out of the 25 Local Government Area in the state are vulnerable to flood, while only six are not vulnerable to flood. Even then, these six LGAs are not completely free of flood events, a small part of these LGAs are vulnerable to flood. These LGAs are Mariga, Munya, Shiroro, Rafi, Gurara and Suleja.The study advocates evolvement and enforcement of an environmental policy to curtail 
INTEGRATING CURVE NUMBER FLOOD MODEL AND GIS

FOR FLOOD VULNERABILITY MAPPING IN NIGER STATE

unstainable agricultural activities on and discourage wanton destruction of environmental sensitive areas for unapproved developments.

\section{REFERENCES}

Adams, W.M., (1985). The Downstream Impacts of Dam Construction: A Case Study from Nigeria. Transactions of the Institute of British Geographers N.S. 10: 292-302.

Adams, W.M. (2000a). Social Impacts of Large Dams: Equity and Distributional Issues, Report to World Commission on Dams. Thematic Review II Social Impacts of Large Dams; Equity and Distributional Issues.

Adams, W.M. (2000b). Social Impacts of Large Dams: Equity and Distributional Issues, Report to World Commission on Dams. Thematic Review II Social Impacts of Large Dams; Equity and Distributional Issues.

Adefolalu, D.O. (1986) Rainfall Trend in Nigeria, Theoretical Application to Climate, Vol 3: 205-209.

Adefolalu, D.O. and Oguntoyinbo, J.S., (2005a). On Rainfall Distribution and Agricultural Planning. Journal of Tropical Geography, vol. 1 (ii), pp. 9-13.

Adefolalu, D.O. and Oguntoyinbo, J.S., (2005b). On Rainfall Distribution and Agricultural Planning. Journal of Tropical Geography, vol. 1 (ii), pp. 9-13.

Center for Climate Change and Freshwater Resources (2009): Eco-climatic Atlas of North-central Nigeria, CCCFWR, Minna. Vol 1 No 1.

David, O.O. and Adebayo W.S. (2012). Assessment of Impact of Hydropower DamsReservoir Outflow on the Downstream River Flood Regime - Nigeria's Experience, Hydropower Practice and Application, Dr. Hossein Samadi-Boroujeni (Ed.), ISBN: 978-953-510164-2, InTech, Available from: assessment-of-impact-of-hydropowerdams-reser voir-outflow-on-the-downstream-river-flood-regime-niger SEPT, 17 2013.

Munich Reinsurance, (2002) Topics: Annual review: Natural catastrophes 2002. Munich Reinsurance 52 p. (http://www.munichre.com). Sept 2003.

Niger State Bureau of Statistics (2011a). Facts and Figures about Niger State, Niger State Statistical Yearbook, 2011 Edition.

Niger State Bureau of Statistics (2011b). Facts and Figures about Niger State, Niger State Statistical Yearbook, 2011 Edition.

Niger State Bureau of Statistics (2011c). Facts and Figures about Niger State, Niger State Statistical Yearbook, 2011 Edition.

Niger State Bureau of Statistics (2011d). Facts and Figures about Niger State, Niger State Statistical Yearbook, 2011 Edition.

National Institute of Occupational Safety and Health (2003). Sand and gravel mining facts. Publication No 2003 - 134, July 1-2. [Online]Available: www.cdc.gov/nios $\mathrm{h} / \mathrm{mining} /$ pubs/pubreference (November 20, 2008).

Ologunorisa, E.T., (2006) Flood Risk Assessment and Management in Nigeria: Perspective from the Niger Delta. Selfers Educational Books. pp. 156. 
Shi, P. and Wang, J. (2010): Atlas of Natural Disaster System of China. Science Press, Bejing. Swaroop, R. (2005) Factors Influencing the Incorporation of Hazard Mitigation During Recovery from Disaster. Journal of Natural Hazards. 22: 185-201.

Timothy, O. (2012). Flood Displaces 8 LG Residents in Bauchi Niger and Taraba States -NEMA. The Sun Newspaper, Thursday, September, 2012. http://www.sunnewsonline.com /webpages/news/national/2011/aug/29/national-29-08-2012-021.html

United Nations. Bureau for Crisis Prevention and Recovery (2005). Reducing Disaster Risk: A Challenge for Development. Accessed at http://www.undp.org/bcpr/disre d/rdr.htm on Sept. 21 .

United State Department of Agriculture-Soil Conservation Service (1972). National Engineering Handbook, Hydrology Section, Chapters 4 -10. Washington, D.C.

Williams, J.R. (1995). The EPIC Model. In Singh, V.P.(ed.): Computer Models of Watershed Hydrology. Water Resources Publication pp. 909-1000. 